been active in stimulating research in other laboratories and in collaborating with other research establishments, both in the United States and abroad. It is best known, however, by the commercial processes that it has evolved (582 U.S. patents) and by its additions to the literature of chemistry and allied sciences (18 books, 122 bulletins, and 1,727 papers). During the past twenty-four years, the Institute has received more than $10,000,000$ dollars from industrial fellowship donors to defray the cost of scientific investigations conducted for these companies and associations. Dr. Weidlein referred to no less than ten new industries that have come from these researches. In conclusion, he said that they hope to occupy the Institute's new building early next year.

\section{Relief of Animal Suffering}

THE ninth Stephen Paget Memorial Lecture of the Research Defence Society was delivered last June by Sir Frederick Hobday, the Principal of the Royal Veterinary College, who chose as his subject "The Relief of Animal Suffering" (The Fight against Disease, 23, No. 3). The attacks of anti-vivisectionists are directed not only against research work for the relief of human suffering, but also against research on diseases of animals, so that the subject of Sir Frederick's address was opportune. After some preliminary remarks on the statistics of the animal population of Great Britain and the diseases that affect them and on the training of the veterinary surgeon, he first mentioned the electric killer. The animal receives a shock of 70 volts by touching it on the head for a few seconds with the instrument connected to a source of electric supply, and it is claimed that the animal is thus rendered unconscious for $2 \frac{1}{2}$ minutes, during which time the blood may be withdrawn. Remarks were then made on articles accidentally swallowed by animals and their treatment, and finally on glanders, mange and other diseases affecting animals, and their prevention and treatment, illustrating everyday cases brought to the veterinary surgeon. At the annual general meeting of the Society, which followed the lecture, the honorary treasurer, Sir Leonard Rogers, pointed out that the expenditure of the Society somewhat exceeds its income, and additional subscriptions and donations would, therefore, be welcome.

\section{Artificial Drying of Grass and Other Fodder}

IN the agricultural world, much has been heard recently of the high nutritive value of grass and fodder crops when cut at a very early stage, and also of the possibility of preserving these special qualities by artificial drying. The Committee appointed by the Agricultural Research Council to investigate these questions has now issued its report, "The Preservation of Grass and other Fodder Crops" (London : H.M. Stationery Office. 1s. net), which provides an up-to-date authoritative account of the whole subject. After surveying the methods at present available for hay-making, ensilage, ete., the committee shows that the artificial drying of grass in the usual hay stage does not promise to be a paying proposition. Drying grass cut young at frequent intervals throughout the season, however, has a good prospect of economic success, particularly in districts of moderate or high rainfall on land in good condition. The report then gives a full account of the methods for cutting and collecting young grass, the physical principles of drying grass, the special practical requirements of a farm drier, the cost of drying and the methods of processing and storage. Descriptions are also given of driers now on the market or those shortly to appear there, those suitable for farm as apart from large-scale factory use receiving special attention. The report concludes with a bibliography for those desirous of still further information.

\section{Safety in Mines Research}

We have received from the Mines Department the thirteenth annual report of the Safety in Mines Research Board for the year 1934. This contains a large amount of interesting and valuable matter. The report proper, after a general introduction, deals with safety instructions, and then there is an important section (Part 3) on the progress of safety researches, dealing with coal-dust explosions, firedamp explosions, spontaneous combustion of coal, mining explosives, falls of ground, haulage, wire ropes and mine ventilation, while the next part deals briefly with various health researches reported by the Health Advisory Committee of the Mines Department. The report is followed by a number of appendixes which are of great importance, and cover the work of the various local committees; it is interesting to see that the value of protective equipment is becoming more widely recognised by the miners.

\section{The Colonial Institute of Holland}

WE have received the annual report of the Royal Colonial Institute, Amsterdam (Koninklijke Vereeniging Koloniaal Instituut, Amsterdam), which has now been in existence for twenty-four years. It gives an account of the activities of the Institute, its funds, the museum, and scientific expeditions, and of the affiliated institutes in the Dutch East Indies. A list of the staff and of their publications is given, together with a summary of the research work carried out. The last-named includes investigations on rhinoscleroma, dengue and food-poisoning, and on the mosquito fauna of Holland.

\section{Meteor Observations in U.S.S.R.}

WITH the object of studying the acceleration of the velocity of a meteor, the Moscow branch of the U.S.S.R. Astro-Geodetical Society has installed a camera of focal ratio $f 2$ behind a two-bladed fan, which interrupts the exposure on a star field nine times per second, at Koutchino, twenty kilometres east of Moscow. Prints of two photographs-one of a meteor and another of a meteor spectrumtogether with a note upon meteor observations, have reached us from Moscow. From a typical example of observations collected (to be described in the Monthly Notices of the Royal Astronomical Society by 
MM. Fedynski and Stanjukowitsch) it appears that the velocity decreases by 37 per cent as the meteor falls from $90 \mathrm{~km}$. to $55 \mathrm{~km}$. in height. The same group of observers conducts observations of meteor spectra with a prismatic camera; forty-seven lines were recognised by $M$. Fedynski in a meteor of stellar magnitude -3 , of which the strongest were those of ionised calcium. A third exposure, made in a camera distant $1.5 \mathrm{~km}$., enables the observers to compute the height of the meteor at any point on its illuminated path.

\section{A Naked-Eye Sunspot}

A GROUP of sunspots, large enough to be seen with the naked eye, has been in transit across the sun's disk (Nov. 3-15), in solar latitude $29^{\circ}$ south; the time of central meridian passage was Nov. $9 \cdot 5$. The group, which was of 'stream' or 'bipolar' type, consisted of a very large circular spot with smaller followers. The leader, with an area of 800 millionths of the sun's hemisphere ( 800 millionths = nearly 950 million square miles), was the largest single spot observed since February 1931; the maximum total area of the present group was 1,200 millionths of the sun's hemisphere. On the few occasions when the weather permitted spectroscopic observations to be made at Greenwich, the group was not unusually active. Observations made on Nov. 9-11 show another large stream of spots extending in longitude for nearly 80,000 miles in lat. $21^{\circ}$ north. The time of central meridian passage was Nov. 13·3. During the last two or three months there has been a marked increase in the sun's general activity, as shown by the increased frequency of spots-mainly of small or moderate size-dark and bright hydrogen and calcium markings on the disk and prominences at the edge of the disk.

\section{Announcements}

THE following have been electea as officers of the Cambridge Philosophical Society for 1935-36. President : Dr. F. W. Aston; Vice-Presidents : Prof. A. Hutchinson, Dr. E. D. Adrian, Sir J. Barcroft; Treasurer: Mr. F. A. Potts ; Secretaries: Mr. F. P. White, Dr. J. D. Cockeroft, Dr. H. Hamshaw Thomas. New Members of the Council: Mr. R. A. Hayos, Dr. F. Kidd, Sir G. P. Lenox-Conyngham, Dr. R. G. W. Norrish.

The fifth German Congress of the Scientific Associations on Corrosion will be held in Berlin on November 18-19. The theme of the Congress will be "The Corrosion of Metallic Materials of Construction by Cold Water". Further information can be obtained from the Verein deutscher Chemiker, Berlin W 35, Potsdamer Str. 103a.

Mr. Cyril C. Barnard, librarian of the London School of Hygiene and Tropical Medicine, Keppel Street, W.C.I, informs us that, in view of the numerous requests he has received for a copy of the classification used by him at that Library, he is considering the issue of a small edition in the form of a cloth-bound volume of 144 pp., royal 8vo., at $10 s .6 d$., containing not only the schedules of the classification but also a full explanatory introduetion, local list, index of parasites, and alphabetical subject index. Mr. Barnard can only undertake publication if sufficient promises of support are fortheoming.

THE following appointments have recently been made by the Secretary of State for the Colonies : F. J. Pound, to be agronomist, Department of Agriculture, Trinidad; N. H. Sands, to be agricultural officer, Malaya; F. W. Toovey, to be botanist, Department of Agriculture, Nigeria; W. E. Miller Logan, to be assistant conservator of forests, Gold Coast; A. C. Russell, to be assistant conservator of forests, Gold Coast ; T. N. Wardrop, to be assistant conservator of forests, Nigeria ; J. B. Alexander, to be geologist, Nyasaland; A. Cawley, to be engineering geologist, Tanganyika; W. H. Reeve, to be assistant field geologist, Tanganyika; B. N. Tem. perley, to be assistant field geologist, Tanganyika; W. J. B. Johnson, to be canning officer, Department of Agriculture, Malaya; A. A. Abraham, assistant agricultural superintendent, to be agricultural superintendent, British Guiana; G. W. Lines, late superintendent of agriculture, to be superintendent of agriculture, Nigeria; T. H. Marshall, senior agricultural assistant, to be district agricultural officer, Tanganyika; R. J. M. Swynnerton, agricultural assistant, to be district agricultural officer, Tan. ganyika.

THE Council of the Institution of Civil Engineers has decided that, in future, the Press can attend and report the discussions at any of the ordinary meetings of the Institution. Abstracts or advance copies of the papers to be read are available on application to the Secretary.

Messrs. Edward Arnold and Co. announce the early publication of a new edition of "The Structure of the Alps" by Prof. Leon W. Collet, of Geneva; and also "The Oyster and the Oyster Fishery" by Prof. J. H. Orton, of the University of Liverpool, embodying the Buckland Lectures for 1935.

Applications are invited for the following appoint. ments, on or before the dates mentioned :

An assistant to the research chemist of the London Shellac Research Bureau-The High Commissionerfor India, General Department, India House, Aldwych, W.C.2 (Nov. 26).

An assistant lecturer and demonstrator in physics. in the University of Leeds-The Registrar (Nov. 26).

A pomologist to the Royal Horticultural SocietyThe Secretary, Royal Horticultural Society, Vincent Square, Westminster, S.W.1 (Nov. 30).

A lecturer in geography and education in the University of Dublin-The Registrar (Dec. 2).

A professor of mining in the University of Edinburgh and Heriot-Watt College-The Secretary of the University (Dec. 31).

An assistant master to teach engineering in the Dover Technical Institute-The Principal. 